\title{
Chorwacki dramat wojenny
}

\author{
Antologija hrvatske ratne drame (1991.-1995.), ur. Sanja Nikčević,
}

Alfa d.d., Zagrzeb 2011, ss. 268

Wydana w 2011 roku Antologija hrvatske ratne drame (1991.-1995.) przygotowana przez Sanję Nikčević, chorwacką teatrolożkę, wykładowczynię uniwersytecką i krytyka teatralnego, ukazuje panoramę chorwackiego dramatu powstałego w czasie wojny w Chorwacji (1991-1995). Uwagę od razu przyciagga udana koncepcja graficzna książki, manifestująca m.in. wyglądem okładki - ukazującej wnętrze zniszczonego w czasie bombardowania teatru w Osijeku - realistyczno-alegoryczny charakter umieszczonych w antologii tekstów.

Książkę otwiera wstęp, w którym autorka definiuje nadrzędną dla Antologii kategorię dramatu wojennego i uzasadnia poszczególne decyzje związane $\mathrm{z}$ wyborem tekstów. Po nim umieszczony został spis sztuk teatralnych wystawionych w latach 1991-2011, wraz z koniecznymi danymi na temat okoliczności ich realizacji scenicznej bądź radiowej. Zasadniczą zaś część publikacji stanowią teksty dramatów, ułożonych według porządku chronologicznego: Dvije sestre Nina Škrabe (1992); Dobrodošli u rat Davora Špišicia (1992); Farsa od Gvere Matka Sršena (1992); Blueblanche, tango, rat Katji Šimunović (1992); Sveti Roko na brdu Milana Grgicia (1992); Živim Lady Martinac/Snježany Sinovčić (1993); Doviđenja u Nuštru Gorana Tribusona (1994); Tatarski biftek Zvonimira Zoričicia (1994); Srijemski put Miroslava Mađera (1995); Smrtonosni povratak Zvonimira Majdaka (1995); Deložacija Miro Gavrana (1995); na końcu opatrzone notami biograficznymi o autorach.

Antologia ukazała się dwadzieścia lat po wybuchu wojny w Chorwacji. Wybór został dokonany ze sporego dystansu czasowego, zarówno względem odzwierciedlonej $\mathrm{w}$ tekstach dającej się usystematyzować i obiektywnie ująć rzeczywistości historycznej, jak i bardziej subtelnej i trudniejszej do uchwycenia rzeczywistości emocji i przeżyć osób zaanga- 
żowanych w tamte wydarzenia. Autorka kierowała się zasadą wyboru dramatów aktualnych i przedstawionych na scenie bądź $\mathrm{w}$ radiu podczas działań wojennych i wtedy też przez publiczność ocenianych i odbieranych. Jednak nadrzędnym kryterium decydującym o umieszczeniu poszczególnych tekstów w Antologii była obecność w nich tematu wojny, jako najważniejszego i dominującego elementu. Nie bez znaczenia okazała się także swego rodzaju produktywność sztuk, ich tematyczno-gatunkowy potencjał umożliwiający kontynuację i dalsze przekształcenia w obrębie np. charakterystyk bohatera i świata przedstawionego. Antologija jest zwiastunem kolejnych zapowiadanych książek, takich jak Antologija poratne drame oraz Antologija poratne komedije.

$\mathrm{Z}$ pewnością estetyczny eksperyment nie jest wyznacznikiem stanowiącym o charakterze zaprezentowanych sztuk. Wszystkie traktują o rzeczywistości skrajnie trudnej, w której twórcy i chorwacka publiczność nie zrezygnowali z tworzenia albo odwiedzania teatru, mimo realnego niebezpieczeństwa. Uczestnictwo w kulturze było formą stawiania oporu, przełamywania strachu, walką przeciwko redukcji potrzeb tylko do tych podstawowych, biologicznych. Spektakle w Osijeku, Zadarze, Zagrzebiu etc. przyciagały widzów, pomimo niesprzyjających i zagrażających bezpieczeństwu i życiu warunków (wojna czasem wdzierała się bezpośrednio w tkankę sztuki, dosłownie przerywając spektakl i zmuszając publiczność do rozejścia się ze wzglądu na zagrożenie bombardowaniem - tak było w przypadku chociażby dramatu Davora Špišicia). Jednak nie tylko sala teatralna była przestrzenią uczestnictwa w teatrze. Innym medium, umożliwiającym kontakt z aktualnie powstającymi dramatami, było radio. Część dramatów ujętych $w$ antologii (siedem) miała swoją premierę na scenie, pozostałe (cztery) zrealizowane zostały jako sztuki radiowe.

Zaprezentowane dramaty funkcjonują w dwu wymiarach czasowych jednym z nich jest czas, gdy powstawały, kondensowały i nazywały rzeczywistość, mobilizując przy tym i jednocząc publiczność i artystów, związanych wspólnym doświadczeniem. Drugim - teraźniejszość, w której można poddać je nie tylko oglądowi teoretycznemu czy krytycznemu, lecz także przekonać się o ich trwałych możliwościach katartycznych.

Istotną wartością książki jest to, że teksty w niej zebrane uzupełniają mapę europejskiego dramatu lat 90., sytuując się niejako na przeciwległym biegunie najbardziej wtedy ekspansywnych tendencji (in-yer-face theatre). 
Dramaty należące do nurtu „reality drama”, charakteryzujące się wprawdzie trafną niekiedy diagnozą społeczną, często podnoszące wartość autoekspresji emocjonalnej do rangi najistotniejszego gestu twórczego, w końcu jednak budzą irytację i niedowierzanie. Chorwacki dramat wojenny ujmuje odbiorcę zasadnością i prawdziwością ukazywanych racji, dylematów, wiarygodnością motywacji postaci.

W dramacie Dvije sestre poruszone zostało zagadnienie wagi więzów rodzinnych i przyjacielskich, których trwałość wystawiona zostaje na próbę w warunkach konieczności określenia się pod względem światopoglądowym i politycznym. Sfera uczuć rodzinnych przenika się ze sferą wyborów motywowanych pragmatycznie bądź ideowo, jednak narastający pomiędzy ludźmi dystans nie jest niemożliwy do pokonania, dzięki dobrej woli i świadomości wspólnoty biografii („Otkucavaju nam zadnje minute. Razgovarajmo o nečem ljepšem, o nečem što nas spaja, ne o onom što nas razdvaja", s. 7). Dobrodošli u rat Davora Špišicia poprzez odniesienia do popularnych wytworów kultury masowej dostarcza refleksji nad parawirtualnym charakterem wydarzeń, rozgrywających się jednak w świecie realnym. Farsa od gvere Matko Sršena, podobnie jak Dvije sestre, jest dramatem, w którym oglądowi poddana została relacja dwu postaci, tym razem mężczyzn. Dubrownik z ,turystycznej metropolii” (s. 43) zamienia się w ,światowe centrum turystyki wojennej” (s. 43), a postaci o różnym statusie społecznym, zbliżone wiekiem i połączone także wątkiem osobistym, giną w ataku artyleryjskim. Blueblanche, tango, rat to sztuka radiowa, w której na plan pierwszy wybija się muzyka, a zwłaszcza motyw tanga. Bohaterkę przygotowującą referat konferencyjny ogarnia nagła melancholia. Źródłem smutku nie jest jednak iluzyjny świat dramatu, którym się zawodowo zajmuje, lecz realność rozpoczynającej się wojny. Płaszczyzna artystycznego doświadczenia i obserwacji aktualnych wydarzeń przenikają się, stwarzając przestrzeń dla ,prywatnego gestu”. Sveti Roko na $b r d u$, którego akcja rozgrywa się w okolicach Zadaru, nastrojem i tonem kontrastuje z poprzedzającym go tekstem. W warunkach zagrożenia bohater sztuki, ksiądz, bardziej troszczy się o zachowanie tradycji, rytuału w sprawowaniu opieki nad świątynią, niż o własne życie. Jego prostota i wiara w nietykalność podstawowych wartości jest niezachwiana, jednak ów idealizm skonfrontowany zostaje z brutalnym działaniem agresora. Świat odwiecznych wartości, obyczaju, codziennej troski, jednym słowem 
ładu i harmonii, jest bezwzględnie niszczony. Akcja Živim dzieje się w Splicie. Marzenia Grofa o nagraniu własnej płyty niszczy wezwanie na front i zdrada przybyłego zza granicy brata, który przywłaszcza sobie jego piosenkę. Społeczność miejska, ważny bohater zbiorowy, po rozproszeniu wykazuje dążenie i zdolność do reintegracji. Doviđenja u Nuštru jest dramatem, w którym postaci dziennikarza zagranicznego i młodego chłopaka szukającego swojego dziadka łączy chorwackie pochodzenie i emigrancka biografia. Dziennikarz przyjeżdża do ogarniętej wojną Chorwacji właściwie tylko po to, by uniknąc przesunięcia w amsterdamskiej gazecie, w której pracuje, do działu plotek i skandali. Nieoczekiwane spotkanie z chłopakiem sprawia, że człowiek kulturowo i mentalnie oddalony od kraju swego pochodzenia, dostrzega związek z miejscem, w którym się znalazł. Tatarski biftek to „męska” sztuka, w której poruszony został problem motywacji skłaniających mężczyzn do wstępowania w szeregi ochotników, obrońców ojczyzny. Okazuje się, że nie zawsze są one wzniosłe, a bohater niekoniecznie przypomina pomnik. Dramat Srijemski put podejmuje temat migracji, poszukiwania domu, wyboru między dobrem osobistym a wspólnym. Smrtonosni povratak to historia człowieka, który w bombardowaniu stracił swoją rodzinę. W Zagrzebiu, dokąd przybywa po zniszczeniu przez Serbów jego domu, nawiązuje kontakt z mafią. Bohater staje się zakładnikiem przestępczego układu, z którego nie ma szans się wyłamać. Deložacija to świetnie napisana komedia, pokazująca, jak mieszkający w Zagrzebiu Chorwat ze zdumieniem odkrywa, że do jego mieszkania wprowadziła się obca kobieta, twierdząca, że teraz to ona zajmować będzie jego lokum. Sztuka dotyka aktualnego wówczas problemu przemieszczeń ludności i związanego z nimi chaosu.

Chorwacki dramat wojenny, jak widać na przykładzie włączonych do Antologii tekstów, nie jest pozbawiony wewnętrznej różnorodności, widocznej chociażby w obrębie gatunku (komedia, musical, spektakl radiowy). Różny jest także stopień demonstrowanego przez autorów dystansu bądź zaangażowania w modelowanie kształtu świata przedstawionego i rządzących nim reguł. Wspólny okazuje się natomiast krag dominujących motywów, jak poszukiwanie i utrata domu (w tym także dążenie do ocalenia świątyni, będącej zarazem także domem szerszej zbiorowości), czy droga do poznania i określenia różnie ujmowanej tożsamości. Ilustrująca ten proces sytuacja rozpadu i naprawy więzi rodzinnych i społecznych, tak 
wyrazista i na różne sposoby powtarzająca się w ukazanych w książce dramatach, uzupełniona została refleksją nad rolą środków masowego przekazu w opisywanym tu świecie dzieł literackich i filmowych.

Można sobie wyobrazić, że możliwy zarzut kierowany pod adresem zamieszczonych w Antologii tekstów dotyczyć będzie stosowanego przez niektórych autorów rozwiązania polegającego na wprowadzaniu szczęśliwego zakończenia konfliktu, możliwego dzięki finalnemu rozpoznaniu bycia „po tej samej stronie” (np. Deložacija, Dvije sestre), albo przyjęciu pozytywnego programu dalszego działania (np. Srijemski put). Swoisty dydaktyzm niektórych spośród włączonych do zbioru tekstów wydaje się jednak zrozumiały i nie umniejsza ich estetycznych i poznawczych walorów. Budowaniu świata nieco wyidealizowanego, jednoznacznego w swym moralnym wydźwięku towarzyszy przecież także ukazywanie skomplikowanych wyborów ludzkich, a więc postaci w działaniu, którymi kierują nie tylko krystalicznie czyste intencje i szlachetne pobudki.

Antologija Sanji Nikčević, prezentująca wybór interesujących, poruszających, zabawnych i skłaniających do refleksji utworów, jest książką wartą także przetłumaczenia. Przedstawienie jej kręgowi odbiorców szerszemu niż tylko specjalistyczny przyczyniłoby się do promowania stosunkowo słabo w Polsce znanego dramatu chorwackiego, którego treści związane z najnowszą historią Chorwacji czytelnik/widz miałby szansę skonfrontować z wytworzonym i utrwalonym przez media obrazem ostatniego konfliktu zbrojnego na terenie byłej Jugosławii.

Lidia Nowicka-Comber 